\title{
Introduction of Some Tree Species of Medicinal and Aromatic Pants (MAPs) in Herbal Garden for Their Ex-situ Conservation
}

\author{
D. K. Patel \\ Department of Rural Technology, Guru Ghasidas Vishwavidyalaya, (A Central University), Bilaspur, 495009, Chhattisgarh, India \\ *Corresponding Author: dplantscience@yahoo.co.in
}

Copyright (C) 2015 Horizon Research Publishing All rights reserved.

\begin{abstract}
Trees are largest life form of the plants. There is a rich diversity of the plants over the world out of them trees registered for their maximum diversity in variable environmental condition. These are erect, branched, long lived plants that are important not only for soil conservation, environmental purification but also useful for their Medicinal and aromatic value for human beings. An herbal garden developed for ex-situ conservation of the Medicinal and aromatic plants in which 23 tree species of medicinally valuable plants belonging to 15 different families were introduced for their ex-situ conservation. Mostly tree species introduced from various places of Chhattisgarh are performing to propagate by their seeds and some also propagated by using other plant parts like Root buds, Stem cutting etc. Each plants having a certain medicinal properties so need for proper care and for their conservation. Tree species of Medicinal and aromatic plants are remarkable for their efficient values for human beings and also important for providing shade to the small herbaceous, shrub nature plants during high temperature range in summer season. These trees were planted in Herbal Garden to achieve the above goals.
\end{abstract}

Keywords Trees, Medicinal Plants, Herbal Garden, Ex-situ Conservation

\section{Introduction}

Trees are a major group of the plants having much height, woody stem and comparatively long life spawn than Herbs and shrubs. These are showing variation in their presence according to the climatic condition as well as their genetic effect. These are also marked for their high degree of seed production useful for their maximum dispersal and long term existence in nature and for slow growth rate.

Trees are of multifold valuable for human beings as are used for timber, fuel fodder and also valuable as medicinal purpose. These are also source of traditional medicines in rural areas of the country. Due to availability and effectiveness these are using continuously by the rural peoples in tribal areas and other parts of the country.

Important medicinal trees of district Bijnor was assessed by Chaudhary et al 2011. Medicinal plants used by tribals of Bandhavgarh National Park (M. P.) India was studied by Srivastava 2011. Phytotherpy among the rural women of district Abbotabad recorded by Shah et al 2013. Diversity and conservation of the Medicinal plants including trees were done by Sharma et al 2011, Barbhuiya et al 2009, Fordjour et al 2008, Pant and Samant 2007, Kasagana et al 2011.

Ex-situ conservation of the medicinal plants were assessed by the researchers like Deshmukh 2010, Kindt et al 2005, Patil 2012, Phartyal et al 2002. Medicinal plants conservation and cultivation by traditional medicine practitioners (TMPs) studied by Oladele et al 2011. Conservation and management of endangered medicinal trees were recorded by Choudhary and Khan 2010, Najar et al 2012, Rai 2014.

\section{Materials and Methods}

Mostly seeds registered as a major source for plant propagation of the tree species of the Medicinal and Aromatic Plants. The seeds were collected from different fields of the Chhattisgarh and were stored and germinate to develop new plants. Some Medicinal and Aromatic Plants prepared plants were also introduced in the Herbal Garden for their further growth and development.

At the site of plantation pit was formed and filled with sand, cow dung/compost, Soil etc. Newly planted plants were provided water and protected against high temperature during summer by covering paper cartoons between 10:00 am to 5:00 pm. This practice was followed during summer season.

During rainy season excess water removed and also 
following better weeding practices near the plants with proper supply of the nutrients. Daily observation was made to analyze the requirements of the plant.

\section{Results \& Discussion}

Selected, collected and propagated Medicinal and Aromatic plants were planted in the field of Herbal Garden followed by scientific methods for successful growth of the plants. The tree species of Medicinal and Aromatic plants which were introduced in Herbal Garden are listed in Table -1 with the related information such as their Common name, Botanical names, Family and Propagation.

Table 1. Tree species of some Medicinal and Aromatic plant (MAPs) and their Regeneration in Herbal Garden.

\begin{tabular}{|c|c|c|c|c|c|}
\hline S. No. & $\begin{array}{l}\text { Common } \\
\text { Name }\end{array}$ & Botanical Name & Family & Propagation & $\begin{array}{l}\text { Mode of Multi- } \\
\text { plication }\end{array}$ \\
\hline 1 & Aagar & Aquilaria crassna Pierre & Thymelaeaceae & Seed & Field \\
\hline 2 & Amaltas & Cassia fistula Linn. & Fabaceae & Seed & Field \\
\hline 3 & $\begin{array}{l}\text { Amaras, } \\
\text { Starfruit }\end{array}$ & Averrhoa carambola $\mathrm{L}$ & Euphorbiaceae & Seed & Field \\
\hline 4 & Amla & Phyllanthus amarus Linn. & Euphorbiaceae & Seed & Field \\
\hline 5 & Guava & Psidium guajava Linn. & Myrtaceae & Seed & Field \\
\hline 6 & Anjeer & Ficus carica $\mathrm{L}$. & Moraceae & Seed & Field \\
\hline 7 & Arjun & Terminalia arjuna Roxb. & Combretaceae & Seed & Field \\
\hline 8 & Bael & Aegle marmelos (L.) Corr. & Rutaceae & Seed & Field \\
\hline 9 & Bahera & $\begin{array}{c}\text { Terminalia bellirica } \\
\text { (Gaertn.) Roxb. }\end{array}$ & Combrataceae & Seed & Field \\
\hline 10 & Bakul, & Mimusops elengi $\mathrm{L}$ & Sapotaceae & Seed & Field \\
\hline 11 & Bija & $\begin{array}{l}\text { Pterocarpus marsupium } \\
\text { Roxb. }\end{array}$ & Fabaceae & Seed & Field \\
\hline 12 & Chandan & Santalum album $\mathrm{L}$. & Santalaceae & Seed & Field \\
\hline 13 & Jamun & Syzygium cumini (L.) Skeels. & Myrtaceae & Seed & Field \\
\hline 14 & Coconut & Cocus nucifera Linn. & Palmae & Seed & Field \\
\hline 15 & Kaitha & Limonia acidissima $\mathrm{L}$. & Rutaceae & Seed & Field \\
\hline 16 & Kathal & Atrocarpus heterophyllus Lam. & Moraceae & Seed & Field \\
\hline 17 & Laxmi taru & Simarouba glauca DC. & Simaroubaceae & Seed & Field \\
\hline 18 & Mango & Mangifera indica Linn. & Anacardiaceae & Seed & Field \\
\hline 19 & Putranjeeva & Lagerstroemia speciosa Linn. & Putranjivaceae & Seed & Field \\
\hline 20 & Salfi & Caryota urens $\mathrm{L}$. & Arecaceae & Seed & Field \\
\hline 21 & Satwan & Alstonia scholaris L.R.Br. & Apocynaceae & Seed & Field \\
\hline 22 & $\begin{array}{c}\text { Star } \\
\text { Gooseberry }\end{array}$ & Phyllanthus acidus (L.) Skeels. & Euphorbiaceae & Seed & Field \\
\hline 23 & $\begin{array}{l}\text { White Siris, } \\
\text { Karhi }\end{array}$ & Albizia procera (Roxb). Benth. & Fabaceae & Seed & Field \\
\hline
\end{tabular}


Introduced Medicinal and Aromatic plants are of different families so their family wise distribution was also recorded and is shown in Table no. - 2. Maximum $03-03$ members of the family Euphorbiaceae, Fabaceae, Myrtaceae and $02-02$ species of belonging to the families like Rutaceae, Mortaceae, Combrataceae were introduced in the Herbal Garden. A total of 24 Medicinal and Aromatic plants of tree habits under 16 varied families were planted.

Table 2. Family wise distribution of MAPs.

\begin{tabular}{|c|c|c|}
\hline S. No. & Family & Total \\
\hline 1 & Rutaceae & 2 \\
\hline 2 & Putranjivaceae & 1 \\
\hline 3 & Anacardiaceae & 1 \\
\hline 4 & Apocynaceae & 1 \\
\hline 5 & Arecaceae & 2 \\
\hline 6 & Combrataceae & 3 \\
\hline 7 & Euphorbiaceae & 3 \\
\hline 8 & Fabaceae & 2 \\
\hline 9 & Moraceae & 2 \\
\hline 10 & Myrtaceae & 1 \\
\hline 11 & Palmae & 1 \\
\hline 12 & Santalaceae & 1 \\
\hline 13 & Sapotaceae & 1 \\
\hline 14 & Simaroubaceae & 23 \\
\hline 15 & Thymelaeaceae & \\
\hline & TOTAL & 1 \\
\hline
\end{tabular}

Medicinal and Aromatic plants were registered for their propagation by seeds. As the tree having long life so need too much care and management during their starting phages of the growth. Gradually as per growth of the plant all needed facilities were provided. Plants were planted following distance to provide them space after their maturation. Pruning practices was also applied for giving the space to the Medicinal and Aromatic plants and for saving loss of energy which help to the plants for fast growth and in certain direction. Proper moisture level was maintained near the grown Medicinal and Aromatic plants. After providing required facilities to the plants that are performing better growth.

\section{Family wise distribution of MAPs}

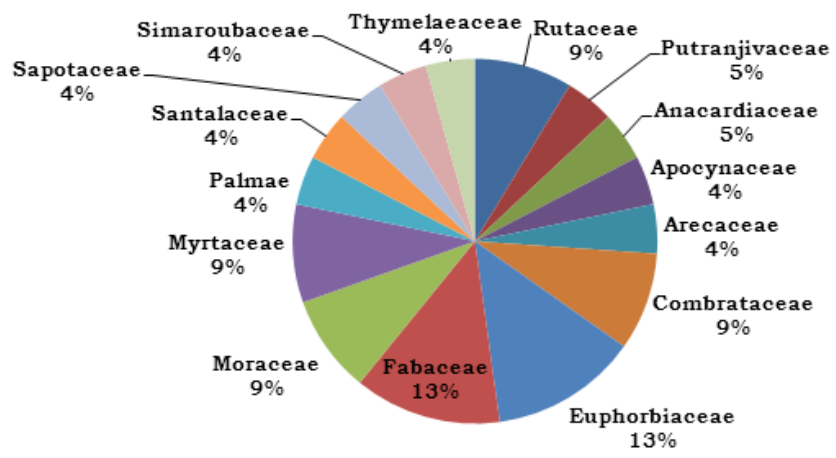

\section{Acknowledgements}

I am cordially thankful to UGC New Delhi for financial support to carry out the current research under Start up Grant on the Topic "Ex - situ Conservation of important Medicinal and Aromatic Plants (MAPs) Resources from Chhattisgarh in Guru Ghasidas Vishwavidyalaya (A Central University) Campus, Bilaspur (C.G.)” No. F. 20 - 17 (3)/2012 (BSR) Dated 8 March 2013.

\section{REFERENCES}

[1] Barbhuiya A. R., Sharma G. D., Arunachalam A. and Deb S. Diversity and conservation of medicinal plants in Barak Valley, Northeast India. Indian Journal of Traditional knowledge. 8 (2) : 169 - 175, 2009.

[2] Biswas B. S. Ex-situ conservation studies on ethnomedicinal rare, endemic plant species from Western Ghats of Maharashtra. International Journal of Pharma and Bio Sciences. 1 (2): 1 -6, 2010.

[3] Choudhary B. and Khan M. L. Conservation and Management of endangered plant species a case study from North east India Bioremediation, Biodiversity and Bioavailability. Global Science books. Pp 47 - 53, 2010.

[4] Choudhary S. and Kumar R. Some important medicinal trees of district Bijnor. Recent research in science and technology. $3(5): 96-100,2011$.

[5] Fordjour P.A., Anning A. K., Jeremiah E., Belford D. and Akonnor D. Diversity and conservation of medicinal plants in the Bomma community of the Brong Ahafo region, Ghana. Journal of medicinal plants research. 2 (9): 226 - 233, 2008.

[6] Kasagana V. N. and Karumuri S. S. Conservation of Medicinal plants (Past, Present and Future trends). Journal of Pharm. Sci. \& Res. 3 (8): 1378 - 1386, 2011.

[7] Kindt R., Noordin Q., Nijui A., and Ruigu S. Biodiversity conservation through Agro forestry: Managing tree species diversity within a network of community based Nongovernmental, Governmental and Research organizations in Western Kenya. 15 th Annual Conference of the Eastern Africa Environmental Network on Networking for Biodiversity. 27 - 28 May. Pp 1-23, 2005.

[8] Nazar Z. A. and Agnihotri S. Need and importance of conservation of endangered tree Oroxylum indicum (Linn.) Vent. Asian Journal of Plant Sciences and Research 2 (3): 220 $-223,2012$.

[9] Oladele A.T., Alade G.O. and Omobuwajo O. R. Medicinal plants conservation and cultivation by traditional medicine preparation (TMPs) in Aiyedaade local Government area of Osun state, Nigeria. Agriculture and Biology journal of North America. 2 (3) : 476 - 487, 2011.

[10] Patil D. S. Ex-situ conservation of Medicinal flora through urban vegetation. Indian Journal of Plant Sciences. 1 (2-3): 19 $-23,2012$.

[11] Phartyal S. S., Thapliyal R. C., Koedam N. and Godefroid S. Ex-situ conservation of rare and valuable forest tree species 
through seed - gene bank. Current Science 83 (11) : 1351 $1357,2002$.

[12] Rai Y. Growth and development of medicinal endangered tree species Aphanamixis polystachya (Wall.) Parker in district Meerut (U. P.) India. International Journal of Multidisciplinary and Current Research. 2 pp 755 - 758, 2014.

[13] Samant S. S. and Pant S. Assessment of plant diversity and prioritization of communities for conservation in Mornaula Reserve Forest. Applied Ecology and Environmental Research 5 (2): 123 - 138, 2007.
[14] Shah G. M., Jamal F. and Hussain M. Phytotherapy among the rural women of district Abbotabad. Pak. J. Bot., 45: $253-$ $261,2013$.

[15] Sharma J., Gaur R. D. and Painuli R.M. Conservation status and diversity of some important plants in the Shiwalik Himalaya of Uttrakhand, India. International Journal of Medicinal and Aromatic Plants. 1 (2): 75 - 82, 2011.

[16] Srivastava N. K. Medicinal plants used by tribals of Bandhavgarh National park (M. P.) India. Indian Journal of Applied and pure Bio. 26 (2): 219 - 222, 2011. 